たれる。筫問 川机理郎(大阪医大). PETは SPECTで代用できるか. 応答 SPECT は PET にくらべ解像度は悪く, 血流障害などの影響を受ける ため問題はあるが，測定時間も短いのでスクリーニン グとしては使用し易いと思われる。質問 関谷 透(山口大)。興味ある所見を示されたが, PET と共に dynamic EEGによる記録比較のデータを持持ちでし たら教示願いたい。応答 Dynamic EEGは行っ ていない。質問 松永 亨(阪大). PET 正常と低
下の各群に扔いて，日常生活のコミュニケーションの 状態に差異はみられなかったか。応答 聴賞連合 野は聴賞刺激以外の色々な入力を受けるので連合野の 活動変化は聴賞刺激だけの問題ではないと思われる。 質問 山下敏夫(関西医大). 測定時の条件として, 音 を与えながら測定されたのか，無音下での测定か。 応答 測定室は騒音が大きいが本報告による症例はほ ぼ蒩であり特に防音装置は使用していない。

\title{
6 正常聴力者の騒音下に扔ける語音聴取
}

\section{吉田雅文・相良哲哉・長野美貴・牧嶋和見（産業医大）}

39 名の健康な青年男女（23～26歳）を被唡者とし， 雑音負荷時の単音節明瞭度について検郡を行った。

方法 検査音の語音として，男女二つの音声テープ を用い，女性音声は $67 \mathrm{~S}$ 語単音節りストの録音テープ を，男性音声は日本音響コンサルタント協会作成の単 音節明瞭度試験用音表テープより $67 \mathrm{~S}$ 単音節語表と同 じ配列に編集したテープを用いた。これらのテープの 再生音 (62dBSPL) をオージオメー夕の白色雑音また は加重雑音とそれぞれ 4 段階の SN 比に mixing した ものをイヤホンを介して1耳に聴かせた。一つの負荷 条件 ( $\mathrm{SN}$ 比)について，それぞれ2表40語を被検者に 聴かせ，聴取した語を用紙に書き取らせた。得られた 冬条件での正答率をロジット変揬し回帰式を求め, こ れより SN 比に対する推定明瞕度を算出した。

結果および考察 得られた推定值と，実例值との重 相関を検定すると，その重相関係数は女性・白色で 0.916 , 女性·加重で 0.849 , 男性・白色て 0.931 , 男性. 加重で 0.992 と危険率 $0.1 \%$ 以下の高い相関を示してい
た。これらの推定明瞭度曲線より正答率 $50 \%$ が得られ る $\mathrm{SN}$ 比 $\left(\mathrm{SN}_{50}\right)$ お占び正答率が $50 \%$ から $70 \%$ に改善 するのに必要な $\mathrm{SN}$ 比の増加 $\left(\mathrm{SN}_{70}-\mathrm{SN}_{50}\right)$ を求めた。 女性検查音の場合には，白色雑音負荷時の $\mathrm{SN}_{50}$ は-1.8 $\mathrm{dB}(-2.7 \sim-0.9: 95 \%$ 信頼区間) で加重雑音負荷時 のそれは $0.4 \mathrm{~dB}(-0.5 \sim 1.4)$ で $\mathrm{SN}_{70}-\mathrm{SN}_{50}$ はとも に $5.2 \mathrm{~dB}$ と, 明瞭度曲線は傾斜が等しく加重雑音で右 側に約 $2 \mathrm{~dB}$ 平行移動していた。これに対して, 男性音 声の場合には, 白色雑音負荷時の $\mathrm{SN}_{50}$ は $-0.2 \mathrm{~dB}(-$ $0.7 \sim 0.7)$ で $\mathrm{SN}_{70}-\mathrm{SN}_{50}$ は 7. 7dB, 加重雑音負荷時の $\mathrm{SN}_{50}$ は $3.2 \mathrm{~dB}(2.6 \sim 3.8)$ で $\mathrm{SN}_{70}-\mathrm{SN}_{50}$ は $3.5 \mathrm{~dB}$ と, 加重雑音負荷時の明瞭度曲線の傾きが白色雑音負 荷時に比べ急峻であり，かつ右側に変位していた。模 查音の基本周波数仙男性音声で $154 \mathrm{~Hz}$, 女性音声で $340 \mathrm{~Hz}$ と1オクターブ以上異なっており,こうした異 なったスペクトルを持つ検查音と，異なった遮需特性 を持つ雑音の組み合わせによりこえらの差異が出現 したものと思われた。

\section{7 耳管狭窄症の耳管機能と内視鏡所見}

\author{
守田雅弘（大阪船員保険）浅井英世（吹田市民）荻野 仁（大手前） \\ 酒井俊一（香川医大）原田 保・松永 亨（阪大）
}

耳管狭窄症の病名は診断的治療である耳管通気によ り生じてきたもので,その耳管機能は不明な点が多い. 今回，これらの耳管狭窄症耳に対して演者の開発した 装置により耳管機能検査や超細径ファイバースコーフ による耳管内の観察を行い, その病態を検討した。

カテーテル通気は定常状態になるまで数回行い耳管 の開大開始圧や通気時の外耳道部での最大音圧を測定 した。通気前後で音響耳管娭查を試行し，通気位に固 定されたカテーテル基部に負荷音源をおいた場合(力 テーテル法)と，カテーテルの代わりにオリーブを鼻入 孔部に扔いた場合(鼻入孔部法)とで比べた。耳管内の 観察は適宜二股式カテーテルにより超細径つアイバー
を用いて行った，音響耳管検査は， $8 \mathrm{kH}$ のバンドノイ ズ負荷時の外耳道部での $8 \mathrm{kH}$ 音圧成分の変化で鰏下 時に一致した音圧の上昇(高さ)を Amplitude, 音圧の 上昇している時間(長さ)を Duration とし， $5 \mathrm{~dB}$ 以上 を陽性とした。

音響耳管検査のカテーテル法と鼻入孔部法とを同一 症例で比較すると, 耳管狭窄症耳に扔いてはカテーテ ル法のみ陽性の群(A群)と正常耳にはなかった両法と も陰性の群(B群)がそれぞれ全体の半数近くを占め た。聑管通気時の耳管開大開始圧は初回通気時には 各々の群間で差はなかったが, 定常状態では, 正常耳 の開大開始圧が減少し，B群において正常耳よりも明 